\title{
The Pro-Environmental Behaviour of Employee in an Apparel Manufacturing Organization in Nuwara-Eliya District of Sri Lanka
}

\author{
Manoharan Vinojini \\ Specialized HRM Research Student \\ Department of Management \\ Eastern University \\ Anthonypillai Anton Arulrajah \\ Senior Lecturer \\ Department of Management, Eastern University
}

\begin{abstract}
The pro-environmental behaviour of employee is a key employee behaviour in the workplace in the context of green organizational behaviour. In general, there are many internal and external factors which promote pro-environmental behaviour of employee. In this context, objective of this paper is to examine the impact of internal and external factors on proenvironmental behaviour of employee in the workplace. Based on the literature review, relevant internal and external factors which can predict pro-environmental behaviour of employee in the workplace were identified. Internal factors include social norms, personal norms and attitude toward pro-environmental behaviour and external factors consist of situational factors, leadership behaviour and leadership support. The primary data were collected through questionnaire from 130 respondents from a selected apparel manufacturing organization in Nuwara-Eliya District of Sri Lanka to achieve the research objective. In order to achieve the study objective, this study applied univariate, correlation and regression analyses. Findings of the study show that both internal and external factors have positive impact on pro-environmental behaviour of employee individually, however in the overall model, only the external factors have positive and significant impact on proenvironmental behaviour of employees. The findings of this study are useful in understanding the impact of selected internal and external factors on pro-environmental behaviour of employee in apparel manufacturing organizations.
\end{abstract}

Key Words: Pro-environmental Behaviour, Internal Factors, External Factors

\section{Introduction}

The environmental sustainability is a key issue facing by the organizations for the last four decades. Many researchers have investigated the negative impact of humankind on the earth and assimilating capacity of the earth (e.g. WWF, 2012; Friends of the earth, 2009). In general, all believe that environmental quality strongly depends on human behaviour patterns. Many environmental problems create a threat to environmental sustainability. According to Opatha (2015), activities and operations of organizations have contributed to the current environmental problems being faced by each nation in the world. They are global warming, urban air pollution, water shortages, environmental noise, and loss of biodiversity. Many of these problems are rooted in human behaviour (Du Nann Winter and Koger, 2004; Gardner and Stern, 2002; Vlekand Steg, 2007) and can thus be managed by changing the relevant human behaviour which may lead to reduce negative environmental impact. In an organizational context, in reducing or eliminating the negative environmental impact of 
business organizations, employees are playing a significant role in the form of their behaviour. This situation raised the question of which factors have an impact on proenvironmental behaviour of employee in the workplace and how this behaviour could be enhanced. The research field of pro-environmental behaviour is emerged to investigate factors influencing on behaviour of people in general as well as behaviour of employees in an organizational context (Blok, Wesselink, Studynka and Kemp, 2015).

According to literature review, pro-environmental behaviour is a kind of behaviour that consciously seeks to minimize the negative impact of one's actions on the natural and built environment (Kollmuss and Agyeman, 2002). According to Blok et al. (2015), research works related with pro-environmental behaviour in the workplace are not sufficiently taken into account in the field of organizational behaviour. They also pointed out that employees spend almost one third of their time in the workplaces, it is expected that their proenvironmental behaviour in the workplace will contribute significantly to the reduction or elimination of the negative impact of employee's actions on the natural and built environment. Hence, this study focuses on pro-environmental behaviour of employee and factors that have an impact on pro-environmental behaviour of employee in the workplace. In order to empirically investigate these concepts (pro-environmental behaviour and factors promoting pro-environmental behaviour of employee in the workplace), this study selected an apparel manufacturing organization in Nuwara-Eliya district of Sri Lanka. Because, the selected apparel manufacturing organization is highly practicing green concept in its manufacturing operations as well as other activities when compared with the other apparel manufactures in that particular district of Sri Lanka. On the other hand, it also has environmental management system certification. According to literature review, this study has identified two main factors (internal and external) which impact on pro-environmental behaviour of employee in the workplace (Blok et al., 2015). However, this was not investigated in the context of Sri Lanka as well as in the context of apparel manufacturing organizations. Hence, in order to fill this empirical knowledge gap this study was conducted with the following research question:

"Whether selected internal and external factors have an impact on pro-environmental behaviour of employee in selected apparel manufacturing organization in Nuwara-Eliya district of Sri Lanka? 'Thus, the objective of this study is to examine the impact of internal and external factors on pro-environmental behaviour of employee in the selected apparel manufacturing organization in Nuwara-Eliya district of Sri Lanka.

\subsection{Pro-environmental Behaviour}

\section{Literature Review}

Human behavior plays a significant role in environmental pollution. Accordingly, organizations and their employees also play an important role on constructing or destructing the environment in which they operate. In this context, one approach to reduce the negative impact and promoting positive environmental impact of organizations on the environment is possible through understanding and promoting pro-environmental behaviour of employee, such as recycling, waste management, reduction in energy consumption or any other behaviour that consciously seeks to minimize the negative impact of one's actions on the environment (Kollmuss and Agyeman, 2002).

Basically, pro-environmental behaviour consciously seeks to minimize the negative impact of one's action on the natural and built world (Kollmuss and Agyeman, 2002). Stern (2000) observes that pro-environmental behaviour is initiated from an individual's intention. Pro- 
environmental behaviour is described as one's act to change the environment back to normal. Kaiser, Doka, Hofststter, and Ranney (2003) mentioned that pro-environmental behaviour is a special type of behaviour of human, such as energy protection, mobility and transportation, waste avoidance, consumerism, recycling, and more social behaviors toward environmental protection.

Employee pro-environmental behaviour has been described "as a broad set of environmentally responsible activities" (Graves, Sarkis and Zhu, 2013, p. 81). BissingOlson, Iyer, Fielding, and Zacher (2013) defined pro-environmental behaviour as the extent to which employees complete their required work tasks in environmentally friendly ways. They also pointed out that it is the extent to which employees take initiative to engage in environmentally friendly behaviour that moves beyond the field of their required work tasks. Pro-environmental behaviour reflects behaviour that harms the environment as little as possible or even benefits it.

Thus far, little is known about environmental behaviour at work and which factors motivate such behaviour in the workplace. As encouraging pro-environmental behaviour at the workplace can result in a significant reduction in environmental problems, it is important to better understand which factors affect pro-environmental behaviour at work.

Hence, the pro-environmental behaviour is commonly said environmentally friendly human behaviour. It is a broad set of environmentally responsible activities. In our routine life we do many activities but we do not know whether they are harmful to the environment. A simple example is to dispose the garbage in proper manner. When we put garbage in a place before that we want to think whether that is a proper place or not. This type of behaviour can also be considered as pro-environmental behaviour in practice. In general, there are many internal as well as external factors impacting the pro-environmental behaviour of employee in the workplace. The next part of this paper deals with internal factors which influence on proenvironmental behaviour of employees in the workplace.

\subsection{Internal Factors and Pro-environmental Behaviour}

According to the literature, several internal factors which influence on pro-environmental behaviour of employee were identified. Mainly, they were identified as social factors, and affective factors. The social factors include social norms and personal norms. At the same time affective factors mainly include the employees' attitudes towards the pro-environmental behaviour.

\subsubsection{Social Factors}

Social factors include personal and social norms. Norms can cover virtually any aspect of individual behaviour. Norms can be defined as individual expectations about a person's behaviour in a particular social situation (Schwartz, 1977). In general, norms are acceptable standards of behaviour within a group that are shared by the group's or organizational members. Norms may help to understand why people diverge from acting in their own selfinterest. With regard to pro-environmental behaviour, Borgstede and Biel (2002) found that personal and social norms are related to the expectations people have with regard to proenvironmental behaviour. Several studies (Matthies, Selge and Klackner, 2012; Ramayah, Lee and Lim, 2012) have shown that social and personal norms have positive association with pro-environmental behaviour. 


\section{Personal Norms}

Nordlund and Garvill (2002) found that personal norms could be viewed as an important general predisposition to act pro-environmentally. Schwartz (1977) describes that the personal norms are attached to the self-concept and experiences as feelings of a moral obligation to perform a certain behaviour. At the same time Thogersen (1999) stated that behavioral regulation are driven by internal rather than external processes, but the personal norms being at least to some extent derived from irrespective of social expectations.

Whether individuals with strong personal norms to act pro-environmentally feel morally obliged to behave accordingly (Scherbaum, Popovich and Finlinso, 2008; Van der Werff, Steg and Keizer 2013). Personal norms can be general, or specific. For example the specific personal norm such as to recycle as well as general environmental personal norms indeed encourage many different pro-environmental behaviour, such as turning off the tap while brushing one's teeth, willingness to pay higher prices for environmentally friendly food, intention to participate in actions to reduce emissions of particle matters, reductions in car use (Nordlund and Garvill, 2002; Van der Werff, Steg and Keizer, 2013).

\section{Social Norms}

Social norms represent the group-shared beliefs about how members of the group should act and behave. Social norms are the accepted standards of behaviour of social groups. They are perceived to be enforceable through reward or punishment (Thøgersen, 1999). If a social norm exists for certain behaviour, people will normally employ this behaviour and perform it. Social norms are unwritten rules about how to behave. They provide us with an expected idea of how to behave in a particular social group or culture. Schwartz (1977) distinguished the social norms, and he views social norms as reflecting the perceived expectations of significant reference persons. The behavioral impact of social norms is thought to be based on social pressure that is the fear of social sanctions.

One of the common approach of social norms to distinguishe between descriptive and injunctive norms (Cialdini, Kallgrenand, Reno, 1991). Based on this approach descriptive norms are to provide information about what appears to be the most appropriate behaviour based on the perception of what other people usually do. For example, people visiting a tourist site may avoid littering when the site looks cleaned-up because it suggests that others have also been making an effort to avoid littering. Injunctive norms reflect beliefs about how one wants to act based on expectations of what other people would morally approve or disapprove of. For example, people visiting a tourist site may avoid littering when they believe that this type of behavior would be sanctioned by other group members (Cialdini et al, 1991).

With regard to pro-environmental behaviour, Borgstede and Biel (2002) found that personal and social norms are related to the expectations people have with regard to proenvironmental behaviour. Based on the literature review on social factors, it is expected that personal and social norms also have a relation with pro-environmental behaviour in the workplace.

\subsubsection{Attitude towards Pro-Environmental Behaviour}

In general, attitude is a key internal factor that affects most of our behaviour. In the workplace, employee attitude towards environment can be considered as an important factor that determines their behaviour towards organizational environmental protection or management initiatives and activities. Hence, this study mainly concerns the employees' 
attitudes toward pro-environmental behaviour in the workplace. Environmental attitudes are fundamentally important, widely discussed, frequently measured, and poorly understood. Environmental attitudes are commonly perceived as preconditions for achieving environmental behaviour.

Attitudes of human are an important factor to determine the behaviour of people. Nowadays environmental attitude of people also become an important one. Environmental attitudes can be recognized as a predictor or determinant of environmental behaviour. Similar to most research on attitudes, studies on environmental attitudes have investigated a variety of constructs such as beliefs, values, intention, and concern. Stern, Dietz and Guagnano (1995) developed a value-based theory for environmental attitudes that includes self-value and the value of all life. Employing this theory, the formation of leader environmental attitudes would initially be associated with personal, societal, or life-centered costs. Attitudes toward the environment seem to have a positive effect on pro-environmental behaviour in the workplace (Meinhold and Malkus, 2005; Barr and Gilg, 2006). With regard to attitudes toward the environment, a positive direct relation with pro-environmental behaviour in the workplace is expected as well. According to Theory of Planned Behaviour (Ajzen, 1991), it is expected that attitudes toward the environment have a positive relationship with proenvironmental behaviour of employee.

\subsection{External Factors and Pro-environmental Behaviour}

The second aspect of this literature review is external factors and pro-environmental behaviour. In this study, these external factors mainly include the situational factors, leadership behaviour and leadership support. The pro-environmental behaviour can be performed only if the required conditions and infrastructure are available, such as opportunities for recycling in the workplace and have the possibility to buy sustainable products etc.

Fliegenschnee and Schelakovsky (1998) concluded that situational factors play a key role in determining pro-environmental behaviour. There are fewer possibilities available to behave pro-environmentally and relatively less number of people are likely to show proenvironmental behaviour in their day to day life. In recent research for instance, it became clear that access to kerbside recycling bins is an important situational factor with a positive impact on recycling behaviour. According to this study, situational factors which are related to pro-environmental behaviour means an individual's circumstances at a given time, represented by access to or knowledge and experience of waste management and environmental protection (Barr, Gilgand Ford, 2001).In general, top management controls organization and its activities as well as employees of the organizations. Thus leadership can be considered as an important external factor from the perspective of employees in an organization. Ramus and Steger (2000) and Egriand Herman (2000) indicate that, the effectiveness of environmental management depends on leadership. The impact of exemplary pro-environmental behaviour by leaders and heads of departments has to be distinguished from leadership support of employees to act pro-environmentally.

Environmental leadership should be provided by a company's top management while the middle management is likely to have a critical impact on employee's attitudes and behaviour (Andersson, Shivarajan, \& Blau, 2005; Daily and Matson, 2008, Ramus and Steger, 2000). Yen and Yen (2012) concluded in their study, leadership is the primary driver of an organization's success in adopting green purchasing standards. 
Robertson and Barling (2012) found that leaders' environmental descriptive norms, leadership and pro-environmental behaviour played an important role in the greening of organizations. Their study showed that the leaders influence their employees in the workplace by sharing values, inspirational motivation, intellectual stimulation, and establishing a relationship with their employees. Based on the literature review on external factors, it is expected that situational factors, leadership support and leadership behaviour positively or negatively impact on pro-environmental behaviour of employees in the workplace.

\subsection{Relationships among Pro-environmental Behaviour, Internal Factors and External Factors}

Various studies have shown the relationship between pro-environmental behaviour, internal factors and external factors. With regard to pro-environmental behaviour, Borgstede and Biel (2002) found that social factors such as personal and social norms are related to the expectations people have with regard to pro-environmental behaviour highly. Similarly, Nordlund and Garvill (2002) found that personal norms could be viewed as an important general predisposition to act pro-environmentally. Various studies have shown a positive correlation between pro-environmental behaviour and personal and social norms (Bamberg and Schmidt, 2003; Bratt, 1999; Fornara, Carrus, Passafaro and Bonnes, 2011; Harland,Staats and Wilke, 1999; Matthieset al., 2012).

Based on the literature reviews on social factors, it is expected that personal and social norms also have a positive relation with pro-environmental behaviour in the workplace. Based on the theory of planned behaviour also it is expected that social norms have a positive relation with the intention to act pro-environmentally. Ajzen (1991) established Theory of planned behaviour, it is one of the more commonly referenced theories in the field of environmental studies and it is a theory explaining human behaviour. It has been applied to studies of the relations among beliefs, attitudes, behavioral intentions and behaviour in various fields (Nye and Hargreaves, 2010).

Attitudes toward the environment also seem to have a positive effect on pro-environmental behaviour. Meinhold and Malkus (2005) found that attitudes significantly predicted proenvironmental behaviour. Similarly Barr and Gilg (2006) showed that environmentalists clearly have a positive, confident and responsible attitude toward environmental protection. With regard to attitudes toward the environment, a positive direct relation with proenvironmental behaviour in the workplace is expected as well. Based on the theory of planned behaviour, it is expected that attitudes toward the environment have a positive relation with the intention to act pro-environmentally.

Robertson and Barling (2012) found that leader's environmental descriptive norms, leadership and pro-environmental behaviour played an important role in the greening of organizations. Their study showed that the leaders influence their employees in the workplace by sharing values, inspirational motivation, intellectual stimulation, and establishing a relationship with their employees. Based on the several literature reviews on external factors, it is expected that situational factors are positively related to proenvironmental behaviour in the workplace. Furthermore, it is expected that proenvironmental behaviour by leaders and leadership support are positively related to proenvironmental behaviour in the workplace. 
Cantor, Morrow and Montabon (2012) demonstrated that leadership support for environmental initiatives leads to enhanced perceptions for respective organizational support. Importantly, at an organizational level, Ones and Dilchert (2012) noted that managerial support and commitment comprises significant facilitators of pro-environmentally sustainable practices. Likewise, Zutshi and Sohal (2004) stressed that top management support results in augmenting employees' commitment to environmental initiatives. Also, prior studies Daily, Bishop and Govindarajulu (2009), Lulfs and Hahn (2013), Ramus and Steger (2000) have substantially argued that supervisor support positively contributes to employees' pro-environmental behaviour. Thus, literature review sufficiently reveals that the internal and external factors have an impact on pro-environmental behaviour in the workplace.

\subsection{Hypotheses of the Study}

Based on the literature, two main hypotheses were formulated to test the influence of internal and external factors on pro-environmental behaviour of employee. Based on the literature review, the following research hypotheses and conceptual model were formulated: The hypotheses are as follows:

$\mathrm{H}_{1}$ : The internal factors have a significant positive impact on pro-environmental behaviour of employee.

$\mathrm{H}_{2}$ : The external factors have a significant positive impact on pro-environmental behaviour of employee.

In general, the conceptual framework is used to illustrate the relationships between the variables, which are involved with a study. Based on the literature review, following conceptual framework was established. In this study, dependent variable is proenvironmental behaviour of employee and independent variables are selected external and internal factors which are associated with and impact on pro-environmental behaviour of employee in the workplace. Figure 1 shows conceptualization framework of this study.

\section{Figure 1: Factors Affecting Pro-environmental Behaviour in the Workplace}

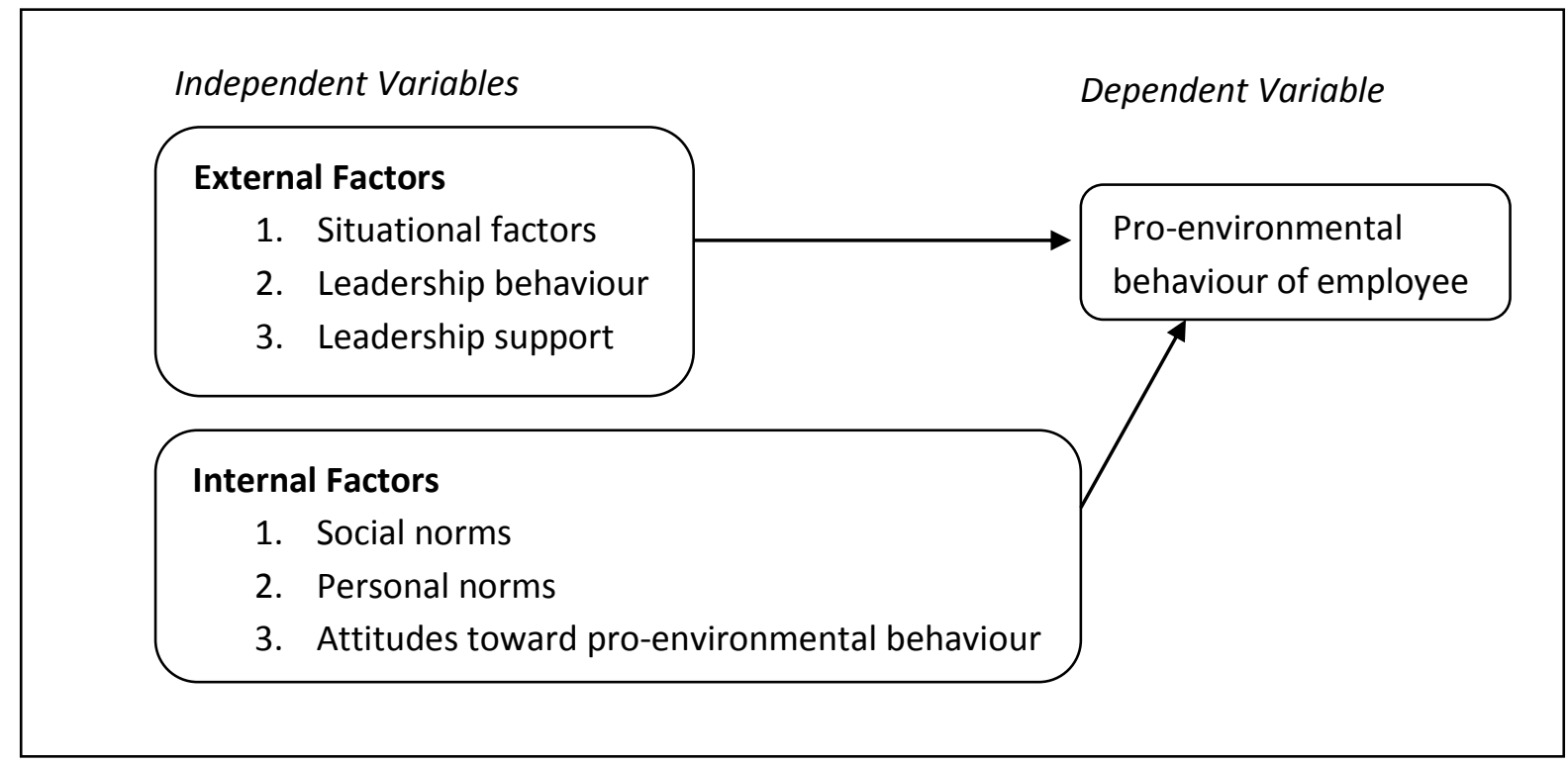

Source: Adopted from Blok, Wesselink, Studynka, and Kemp (2015) 


\section{Research Method}

\subsection{Procedure and Participants}

A cross-sectional study was conducted among the 130 employees of an apparel manufacturing organization in Nuwara-Eliya district of Sri Lanka by using questionnaire based survey method. The researchers did not interfere with the normal activities in the selected apparel manufacturing organization. This study was conducted in a non-contrived setting and unit of analysis was the individual employee. The stratified random sampling method was used to select the sample respondents from the population (see Table 1).

Table 1: Sampling Framework

\begin{tabular}{|l|l|c|c|}
\hline No. & Department & Population & Sample \\
\hline 1 & Cutting Department & 60 & 15 \\
\hline 2 & Machine Operators & 280 & 68 \\
\hline 3 & Ironing Department & 35 & 9 \\
\hline 4 & Quality Checking Department & 64 & 15 \\
\hline 5 & Work Study Department & 50 & 12 \\
\hline 6 & Packing Department & 45 & 11 \\
\hline \multicolumn{2}{|c|}{ Total } & $\mathbf{5 3 4}$ & $\mathbf{1 3 0}$ \\
\hline
\end{tabular}

\subsection{Questionnaire and Measures}

This study mainly considers the primary data. The primary data were collected through a closed structured questionnaire from 130 respondents. The study questionnaire consists of 5 questions regarding the profile of the respondent and 32 questions representing the research information. In the questionnaire, pro-environmental behaviour and the internal and external factors were operationalized (see Appendix-1).

The questionnaire structure for this study is based on two parts, which are personal information and research information. Personal information consists of gender, age, educational qualification, job title and working experience. Similarly research information consists of research concepts such as pro-environmental behaviour of employees, external factors and internal factors. The study used the five point Likert scale, where respondents are required to mark either strongly disagree, disagree, neutral, agree and strongly agree independently 1,2,3,4 and 5 .

In the study the univariate analysis was used to measure the level of internal, external and pro-environmental behaviour of employee. Correlation and regression analyses were used to determining the relationship and impact of internal and external factors on pro-environmental behaviour of employees.

\subsection{Demographic Profile of Respondents}

\section{Findings and Discussion}

Among 130 of employees 66.9\% (87) of the employees are female, remaining $33.1 \%$ (43) respondents are male, the female employees are more than the male employees. Among them $46.2 \%$ (60) of the employees come under the age group of 20-30 years. It concluded that in this selected organization most of the employees are working under the age group of 20-30 years. Based on the education qualification $67.7 \%$ (88) of employees are with the qualification of ordinary level. In this apparel manufacturing organization most of the employees are working with education qualification of ordinary level. Based on the job title $50 \%$ (65) of employees are working as machine operators. Most of the employees are 
working as machine operators in the selected apparel manufacturing organization. Based on the working experience $53.1 \%$ (69) of employees work with below 5 years of working experience, most of the employees are having less years of working experience.

\subsection{Reliability Analysis}

Refer to Table 2.

Table 2: Reliability Analysis for Overall Variables

\begin{tabular}{|l|c|c|}
\hline Variables & $\begin{array}{c}\text { Cronbach's Alpha } \\
\text { Value }\end{array}$ & $\begin{array}{c}\text { No. of Question } \\
\text { Items }\end{array}$ \\
\hline External Factors & 0.815 & 11 \\
\hline Internal Factors & 0.748 & 08 \\
\hline Pro-environmental Behaviour & 0.888 & 13 \\
\hline
\end{tabular}

According to the Table 2 that is about the overall reliability analysis, Cronbach's Alpha Coefficient for the external factors is 0.815 , for internal factors it is 0.748 and for proenvironmental behaviour it is 0.888 . When the Cronbach's Alpha Coefficient value is above 0.70 , it is considered as a good reliable instrument. In this study Cronbach's Alpha Coefficient values are $0.815,0.748$ and 0.888 so it is indicated that all items considered in this study are to be acceptable.

\subsection{Univariate Analysis}

Refer to Table 3.

Table 3: Overall View of Univariate Analysis

\begin{tabular}{|c|c|c|c|c|}
\hline Variable and Dimension & $\begin{array}{c}\text { No. of } \\
\text { Respondents }\end{array}$ & Mean & $\begin{array}{l}\text { Std. } \\
\text { Deviation }\end{array}$ & Level* \\
\hline External Factors & 130 & 4.07 & .537 & High level \\
\hline Situational Factors & 130 & 4.02 & .787 & High level \\
\hline Leadership Behaviour & 130 & 3.94 & .715 & High level \\
\hline Leadership Support & 130 & 4.16 & .599 & High level \\
\hline Internal Factors & 130 & 4.49 & .429 & High level \\
\hline Social Norms & 130 & 4.45 & .661 & High level \\
\hline Personal Norms & 130 & 4.71 & .422 & High level \\
\hline $\begin{array}{l}\text { Attitude toward pro- } \\
\text { environmental behaviour }\end{array}$ & 130 & 4.41 & .583 & High level \\
\hline $\begin{array}{l}\text { Pro-environmental } \\
\text { behaviour }\end{array}$ & 130 & 3.87 & .685 & High level \\
\hline
\end{tabular}

Table 3 shows that the overall mean value of internal factors is 4.49 it is deviated from 0.429 . It shows that the dimensions of internal factors have a higher level among the employees of the surveyed organization. The overall mean value of external factors is 4.07 and it has standard deviation of 0.537 . It shows that the dimensions of external factors are also at a higher level among the employees of the surveyed organization. And overall mean value of pro-environmental behaviour is 3.87 and it has standard deviation of 0.685 . It shows the 
actual status quo of pro-environmental behaviour among the employees of the surveyed organization.

\subsection{Correlation and Regression Analyses}

Refer to Table 4.

Table 4: Overall View of Correlation and Regression Analyses

\begin{tabular}{|c|c|c|c|c|c|}
\hline \multicolumn{2}{|c|}{ Variable and Dimension } & $\begin{array}{r}\text { External } \\
\text { Factors } \\
\end{array}$ & $\begin{array}{r}\text { Internal } \\
\text { Factors }\end{array}$ & \multicolumn{2}{|c|}{$\begin{array}{l}\text { Both Internal } \\
\text { and External }\end{array}$} \\
\hline \multicolumn{2}{|c|}{ Pearson Correlation (r) } & .547 & .409 & & .599 \\
\hline \multicolumn{2}{|c|}{ Sig. (2-tailed) } & .000 & .000 & & \\
\hline \multicolumn{2}{|c|}{$\begin{array}{l}\text { Sum of Squares and Cross- } \\
\text { products }\end{array}$} & 25.976 & 15.510 & & \\
\hline \multicolumn{2}{|c|}{ Covariance } & .201 & .120 & & \\
\hline \multicolumn{2}{|l|}{$\mathrm{N}$} & 130 & 130 & & \\
\hline \multicolumn{2}{|c|}{ Hypothesis of the study } & $\begin{array}{r}\mathrm{P}<0.05 \\
\mathrm{H} 1: \text { Accept }\end{array}$ & $\begin{array}{r}\mathrm{P}<0.05 \\
\mathrm{H} 2: \text { Accept }\end{array}$ & & \\
\hline \multicolumn{2}{|c|}{ R Square } & .299 & .167 & & .312 \\
\hline \multicolumn{2}{|c|}{ Adjusted R Square } & .293 & .161 & & .301 \\
\hline \multicolumn{2}{|c|}{ Std. Error of the Estimate } & .57619 & .62791 & & .57292 \\
\hline \multicolumn{2}{|c|}{ R Square Change } & .299 & .167 & & .312 \\
\hline \multicolumn{2}{|c|}{ F Change } & 54.590 & 25.745 & & 28.839 \\
\hline \multirow{2}{*}{\multicolumn{2}{|c|}{ Sig. F Change }} & .000 & .000 & & .000 \\
\hline & & & & External & Internal \\
\hline \multicolumn{2}{|c|}{$\begin{array}{l}\text { Unstandardized Coefficients } \\
\text { (Beta) }\end{array}$} & 0.698 & 0.654 & 0.594 & 0.226 \\
\hline \multicolumn{2}{|c|}{$\begin{array}{l}\text { Standardized Coefficient } \\
\text { (Beta) }\end{array}$} & 0.547 & 0.409 & 0.465 & 0.141 \\
\hline \multicolumn{2}{|c|}{ Std. Error } & 0.094 & 0.129 & 0.115 & 0.144 \\
\hline \multicolumn{2}{|l|}{ t-value } & 7.425 & 5.069 & 5.172 & 1.570 \\
\hline \multicolumn{2}{|l|}{ Sig. } & .000 & .000 & .000 & .119 \\
\hline \multirow{2}{*}{$\begin{array}{l}95 \% \\
\text { confidence } \\
\text { interval for B }\end{array}$} & $\begin{array}{l}\text { Lower } \\
\text { Bound }\end{array}$ & 0.511 & .399 & .367 & -.059 \\
\hline & $\begin{array}{l}\text { Upper } \\
\text { Bound }\end{array}$ & 0.883 & .910 & .821 & .511 \\
\hline
\end{tabular}

Table 4 shows the correlation of coefficient (r) was $0.409^{* *}$, which was significant at 0.01 level. Since the $r>0$, p-value is less than 0.01 , it shows that the correlation between internal factors and pro-environmental behaviour was positive and significant, and the two variables were linearly associated. The adjusted R- Square is 0.161 which implies that only $16.1 \%$ of pro-environmental behaviour is explained by internal factors. Regression result indicates that the significance of $t$ value is less than 0.05 and the $b$ value of internal factor is 0.654 , it indicates that if internal factors increase by one point pro-environmental behaviour gets increased by 0.654 . Based on the evidence it is concluded that the internal factors have a positive impact on pro-environmental behaviour of employee. So the first hypothesis of the study was accepted. 
H1: The internal factors have a significant positive impact on pro-environmental behaviour of employee.

Similarly previous studies (Borgstede and Biel, 2002) also found that under the internal factors, social factors such as personal and social norms are positively related to the expectations people have with regard to pro-environmental behaviour highly. Similarly, Nordlund and Garvill (2002) found that personal norms could be viewed as an important general predisposition to act pro-environmentally. Likewise Meinhold and Malkus (2005) found that attitudes toward pro-environmental behaviour significantly predicted proenvironmental behaviour of employee.

Table 4 shows the correlation of coefficient (r) was $0.547^{* *}$, which was significant at 0.01 level. Since the $r>0, p$-value is less than 0.01 , it shows that the correlation between external factors and pro-environmental behaviour was positive and significant and the two variables were linearly associated. The adjusted R- Square is 0.293 which implies that $29.3 \%$ of proenvironmental behaviour is explained by external factors. Regression result indicates that the significance of $t$ value is less than 0.05 and the $b$ value of internal factor is 0.698 . It indicates that, if external factors increase by one point pro-environmental behaviour increases by 0.698. Based on the evidence it is concluded that the external factors have a significant positive impact on pro-environmental behaviour of employee. Thus the second hypothesis of the study was accepted.

H2: The external factors have a significant positive impact on pro-environmental behaviour of employee.

Similarly previous studies also found the impact of external factors on pro-environmental behaviour. Fliegenschnee and Schelakovsky (1998) concluded that situational factors play a key role in determining pro-environmental behaviour. Similarly Ramus and Steger (2000) have substantially argued that leadership support positively contributes to employee's proenvironmental behaviour. Robertson and Barling (2012) found that leader's environmental descriptive norms, leadership and pro-environmental behaviour played an important role in the greening of organizations.

And based on the multiple linear regression analysis the Adjusted R-Square is 0.301 which implies that $30.1 \%$ of pro-environmental behaviour is explained by internal and external factors. Regression result indicates that the significant of $t$ value of internal factors is 0.119 , it is more than 0.05 and the $b$ value of internal factors is 0.226 . According to the findings of this study, it indicates that internal factors of employees do not have a significant impact on pro-environmental behaviour of employees in the surveyed apparel manufacturing organization. At the same time, the significance of $t$ value for external factors is 0.000 , it is less than 0.05 and the $b$ value of external factors is 0.594 . This finding indicates that external factors have a significant impact on pro-environmental behaviour of employees in surveyed apparel manufacturing organization. Based on the findings of multiple linear regression analysis, it can be concluded that only the external factors have a significant impact on proenvironmental behaviour of employees in the surveyed apparel manufacturing organization.

\section{Conclusion, Recommendations and Limitations}

The results were obtained through the collected data from target respondents of 130 employees and were analyzed by using univariate, correlation and regression techniques. Based on this univariate analysis, both the internal and external factors were at higher level 
and pro-environmental behaviour of employee also was at higher level among the employees of the surveyed apparel organization.

Based on the findings of correlations and simple regression analyses, individually both the internal and external factors have positive associations and impacts on pro-environmental behaviour of employee. But analyzing both internal and external factors together by using multiple linear regression analysis, finding revealed that only the external factors have a significant impact on pro-environmental behaviour of employees. The internal factors have a positive impact on pro-environmental behaviour but it is not a significant impact on proenvironmental behaviour of employees in the surveyed apparel manufacturing organization.

\subsection{Recommendations}

The study has some recommendations for future researchers such as, by understanding the variables of this study that will influence employees and their leader's behaviour favorably to their working environment and to increase the productivity in their working environment in efficient manner, they should be able to develop more effective pro-environmental behaviour in order to save their working environment, leaders of apparel manufacturing organizations should keep in mind that their support is a good predictor to improve pro-environmental behaviour of employees, so they want to give their full support to their employees in order to improve their environmental concern and also if they adopt proper leadership styles and behaviour in their organizations that is also to improve employees' performance to the environmental aspects.

The findings show a less positive impact of internal factors of employee such personal norms and poor attitudes on pro-environmental behaviour, therefore the organization should provide a sufficient environmental training to improve the pro-environmental behaviour of employees. Apart from these, surveyed manufacturing and similar other organizations should implement green human resource management practices (Opatha, 2013; Opatha and Arulrajah, 2014; Arulrajah, Opatha, and Nawaratne, 2015) in order to improve employees' environmental attitudes and their personal norms in relation to environmental behaviour that will improve organizations performance in environmentally sustainable manner.

\subsection{Limitations}

This study focused only on one apparel manufacturing organization with a limited sample size and only considered selected internal and external factors and their impact on proenvironmental behaviour of employee by using questionnaire based survey. Therefore, the same research can be extended to other apparel organizations as well as organizations in other sectors such as banking sectors, financial institutions, hotel industry and construction companies by collecting data from a larger sample size and deploying mixed research methods or approaches, because this study used only the quantitative approach, using qualitative research data collection methods such as interviews and observation would be effective to get more explanation regarding pro-environmental behaviour of employee.

\section{References}

Ajzen, I. (1991), The theory of planned behavior, Organizational Behavior and Human Decision Processes, Vol. 50, No. 2, pp. 179-211.

Andersson, L., Shivarajan, S. and Blau, G. (2005), Enacting ecological sustainability in the MNC: A test of an adapted value-belief-norm framework, Journal of Business Ethics, Vol. 59, No. 3, pp. 295-305. 
Arulrajah, A. A., Opatha, H. H. D. N. P. and Nawaratne, N. N. J. (2015), Green Human Resource Management Practices: A Review, Sri Lankan Journal of Human Resource Management, Vol. 5, No. 1, pp. 1-16.

Bamberg, S. and Schmidt, P.(2003), Incentives, morality, or habit? Predicting students' car use for university routes with the models of Ajzen, Schwartz, and Triandis, Environment and Behavior, Vol. 35, No. 2, pp. 264-285.

Barr, S. and Gilg, A.(2006), Sustainable lifestyles: Framing environmental action in and around the home, Geoforum, Vol. 37, No. 6, pp. 906-920.

Barr, S., Gilg, A. W. and Ford, N. J.(2001), A conceptual framework for understanding and analyzing attitudes towards household-waste management, Environment and Planning, Vol. 33, No. 11, pp. 2025-2048.

Bissing-Olson., M J., Iyer, A., Fielding, K. S. and Zacher, H. (2013), Relationships between daily affect and pro-environmental behavior at work: The moderating role of pro-environmental attitude, Journal of Organizational Behavior, Vol. 34, No. 2, pp.156-175.

Blok,V.,Wesselink, R., Studynka, O. and Kemp, R. (2015), Encouraging sustainability in the workplace: a survey on the pro-environmental behaviour of university employees, Journal of Cleaner Production, Vol. 106, pp. 55-67.

Borgstede, C.V. and Biel,A,(2002), Pro-environmental Behaviour: Situational Barriers and Concern for the Good at Stake, Goteborg Psychological Reports, Vol. 32, No. 1, pp.1-9.

Bratt, C. (1999), The impact of norms and assumed consequences on recycling behavior, Environment and Behavior, Vol. 31, No. 5, pp. 630-656.

Cantor, D. E., Morrow, P. C. and Montabon, F. (2012), Engagement in environmental behaviors among supply chain management employees: An organizational support theoretical perspective, Journal of Supply Chain Management, Vol. 48, No. 3, pp. 3351.

Cialdini, R. B., Kallgren, C. A. and Reno, R. R. (1991), A focus theory of normative conduct: A theoretical refinement and reevaluation of the role of norms in human behavior, Advances in Experimental Social Psychology, Vol. 24, pp. 201-234.

Daily, B. F., Bishop, J. W. and Govindarajulu, N. (2009), A conceptual model for organizational citizenship behavior directed toward the environment, Business \& Society, Vol. 48, No. 2, pp. 243-256.

Daily, G. C. and Matson, P.A.(2008), Ecosystem services: From theory to implementation, Proceedings of the National Academy of Sciences of the United States of America, Vol.105, No. 28, pp. 9455-9456.

DuNann Winter, D. and Koger, S. M. (2004), The Psychology of Environmental Problems ( $2^{\text {nd }}$ ed.), Lawrence Erlbaum Associates, Mahwah, New Jersey.

Egri, C.P. and Herman, S.(2000), Leadership in the North American environmental sector: Values, leadership styles, and contexts of environmental leaders and their organizations, Academy of Management Journal, Vol. 43, No. 4, pp. 571-604.

Fliegenschnee, M. and Schelakovsky, A. (1998), Umwelt psychologie und Umweltbildung: EineEinführungaushumanökologischerSicht, Facultas-Univ. Verl., Wien.

Fornara, F., Carrus, G., Passafaro, P. and Bonnes, M.(2011), Distinguishing the sources of normative influence on pro environmental behaviors the role of local norms in household waste recycling, Group Processes \& Intergroup Relations, Vol. 14, No. 5, pp. 623-635.

Friends of the Earth (2009), Overconsumption, Our Use of the World's Natural Resources, Friends of the Earth, Washington. 
Gardner, G.T. and Stern, P. C.(2002), Environmental Problems and Human Behavior( $2^{\text {nd }}$ ed.), Pearson Custom Publishing, Boston.

Graves, L. M., Sarkis, J. and Zhu, Q.(2013), How transformational leadership and employee motivation combine to predict employee pro-environmental behaviors in China, Journal of Environmental Psychology, Vol. 35, pp. 81-91.

Harland, P., Staats, H. and Wilke, H. A.(1999), Explaining pro-environmental intention and behavior by personal norms and the theory of planned behavior, Journal of Applied Social Psychology, Vol. 29, No. 12, pp. 2505-2528.

Kaiser, F. G., Doka, G., Hofstetter,P. and Ranney, M. A.(2003), Ecological behavior and its environmental consequences: A life cycle assessment of a self-report measure, Journal of Environmental Psychology, Vol. 23, No. 1, pp.11-20.

Kollmuss, A. and Agyeman, J.(2002), Mind the gap why do people act environmentally and what are the barriers to pro-environmental behaviour?, Environmental Education Research, Vol. 8, No. 3, pp. 239-260.

Lülfs, R. and Hahn, R.(2013), Corporate greening beyond formal programs, initiatives, and systems: a conceptual model for voluntary pro-environmental behavior of employees, European Management Review, Vol. 10, No. 2, pp. 83-98.

Matthies, E., Selge, S. and Klöckner, C. A.(2012), The role of parental behaviour for the development of behaviour specific environmental norms-The example of recycling and re-use behaviour, Journal of Environmental Psychology, Vol. 32, No. 3, pp. 277284.

Meinhold, J. L. and Malkus, A. J. (2005), Adolescent environmental behaviors can knowledge, attitudes, and self-efficacy make a difference, Environment and Behavior, Vol. 37, No.4, pp. 511-532.

Nordlund, A. M. and Garvill, J. (2002), Value structures behind pro-environmental behavior, Environment and Behavior, Vol. 34, No. 6, pp. 740-756.

Nye, M. and Hargreaves, T.(2010), Exploring the social dynamics of pro-environmental behavior change, Journal of Industrial Ecology, Vol. 14, No. 1, pp. 137-149.

Ones, D. S. and Dilchert, S.(2012), Environmental sustainability at work: A call to action, Industrial and Organizational Psychology, Vol. 5, No. 4, pp. 444-466.

Opatha, H.H.D.N.P. (2013), Green Human Resource Management: A Simplified Introduction, Proceedings of the HR Dialogue 2013, Department of HRM, University of Sri Jayewardenepura, pp. 21-41.

Opatha, H.H.D.N.P. (2015), Organizational Behaviour, The Human Side of Work, Dept of HRM, University of Sri Jayewardenepura, Colombo: Sri Lanka.

Opatha, H.H.D.N.P. and Arulrajah, A.A. (2014), Green Human Resource Management: Simplified General Reflections, International Business Research, Canadian Center of Science and Education, Vol. 7, No. 8, pp. 101-112.

Ramayah, T., Lee, J. W. C. and Lim, S.(2012),Sustaining the environment through recycling: an empirical study, Journal of Environmental Management, Vol. 102, pp. 141-147.

Ramus, C. A. and Steger, U.(2000), The Roles of Supervisory Support Behaviors and Environmental Policy in Employee "Ecoinitiatives" at Leading-Edge European Companies, Academy of Management Journal, Vol. 43, No. 4, pp. 605-626.

Robertson, J. L. and Barling, J. (2012), Greening Organizations through Leaders' Influence on Employees'Pro-environmental behaviors, Journal of Organizational Behavior, Vol. 34, No. 2, pp.176-194.

Scherbaum, C. A., Popovich, P. M. and Finlinson, S.(2008), Exploring Individual-Level Factors Related to Employee Energy-Conservation Behaviors at Work, Journal of Applied Social Psychology, Vol. 38, No. 3, pp. 818-835. 
Schwartz, S. H.(1977), Normative influences on altruism, Advances in Experimental Social Psychology, Vol. 10, pp. 221-279.

Stern, P. C., Dietz, T. and Guagnano, G. A.(1995), The new ecological paradigm in socialpsychological context, Environment and Behavior, Vol. 27, No. 6, pp. 723-743.

Stern, P.C. (2000), New environmental theories: toward a coherent theory of environmentally significant behavior, Journal of Social Issues, Vol. 56, No. 3, pp. 407-424.

Thygersen, J.(1999), The ethical consumer, moral norms and packaging choice, Journal of Consumer Policy, Vol. 22, No. 4, pp. 439-460.

Van der Werff, E., Steg, L. and Keizer, K. (2013), It is a moral issue: The relationship between environmental self-identity, obligation-based intrinsic motivation and proenvironmental behaviour, Global Environmental Change, Vol. 23, No. 5, pp. 12581265.

Vlek, C. and Steg, L.(2007), Human Behavior and Environmental Sustainability: Problems, Driving Forces, and Research Topics, Journal of Social Issues, Vol. 63, No.1, pp. 119.

WWF (2012), Living Planet Report. WFF, Gland.

Yen, Y. X. and Yen, S. Y.(2012), Top-management's role in adopting green purchasing standards in high-tech industrial firms, Journal of Business Research, Vol. 65, No. 7, pp. 951-959.

Zutshi, A. and Sohal, A. S.(2004), Adoption and maintenance of environmental management systems: critical success factors, Management of Environmental Quality: An International Journal, Vol. 15, No.4, pp. 399-419.

\section{Appendix-1: Questionnaire of the study}

\section{Part I - Personal Information}

Please mark " $X$ " in appropriate boxes or fill the details in the space provided.

01. Gender:

Male

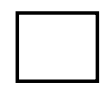

Female

02. Age Group:

Below 20 years

31-40 years

Above 51

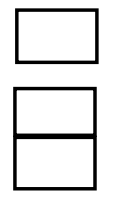

20-30 years

41-50 years

03. Educational Qualification

Primary level

Ordinary level

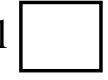

Advanced level

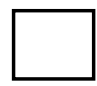

Graduate

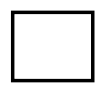

04. Job Title

05. Working Experience

Below 5 years
5-10 years

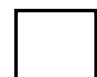

Above 10 years
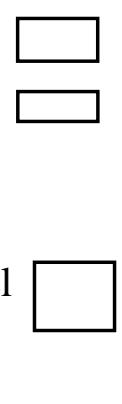


\section{Part II - Research Information}

\section{Please mark " $X$ " in appropriate boxes by considering the following scale.}

Strongly disagree (SD) - $\quad 1$

Disagree (D) - $\quad 2$

Neutral $(N) \quad-\quad 3$

Agree (A) - 4

Strongly Agree (SA) $\quad-\quad 5$

\begin{tabular}{|c|c|c|c|c|c|c|}
\hline \multicolumn{2}{|c|}{ Variables } & $\begin{array}{c}\text { SD } \\
1\end{array}$ & $\begin{array}{l}\mathbf{D} \\
\mathbf{2}\end{array}$ & $\begin{array}{l}\mathbf{N} \\
\mathbf{3}\end{array}$ & $\begin{array}{c}\mathbf{A} \\
4\end{array}$ & $\begin{array}{c}\mathbf{S A} \\
\mathbf{5}\end{array}$ \\
\hline \multicolumn{7}{|c|}{ 1. External factors } \\
\hline \multicolumn{7}{|c|}{ Situational factors } \\
\hline 01 & $\begin{array}{l}\text { My company provides good possibilities to show the pro- } \\
\text { environmental behaviour. }\end{array}$ & 1 & 2 & 3 & 4 & 5 \\
\hline 02 & $\begin{array}{l}\text { The current facilities for recycling are sufficient at my } \\
\text { working place. }\end{array}$ & 1 & 2 & 3 & 4 & 5 \\
\hline \multicolumn{7}{|c|}{ Leadership Behaviour } \\
\hline 03 & $\begin{array}{l}\text { I show the pro-environmental behaviour, when my } \\
\text { supervisor/ head of the department behaves pro- } \\
\text { environmentally in the workplace. }\end{array}$ & 1 & 2 & 3 & 4 & 5 \\
\hline 04 & $\begin{array}{l}\text { It is important to me that my supervisor/head of the } \\
\text { department shows pro-environmental behaviour at work. }\end{array}$ & 1 & 2 & 3 & 4 & 5 \\
\hline 05 & $\begin{array}{l}\text { Seeing my supervisor/ head of the department acting pro- } \\
\text { environmentally influences my own acting. }\end{array}$ & 1 & 2 & 3 & 4 & 5 \\
\hline \multicolumn{7}{|c|}{ Leadership Support } \\
\hline 06 & $\begin{array}{l}\text { My supervisor/ head of the department supports me in } \\
\text { showing pro-environmental behaviour at work. }\end{array}$ & 1 & 2 & 3 & 4 & 5 \\
\hline 07 & $\begin{array}{l}\text { My manager/ supervisor informs me about the } \\
\text { environmental impact of my behaviour at work. }\end{array}$ & 1 & 2 & 3 & 4 & 5 \\
\hline 08 & $\begin{array}{l}\text { My manager/ supervisor informs me about projects on } \\
\text { sustainability at my company. }\end{array}$ & 1 & 2 & 3 & 4 & 5 \\
\hline 09 & $\begin{array}{l}\text { My manager/ supervisor informs me about environmental } \\
\text { policy of my company. }\end{array}$ & 1 & 2 & 3 & 4 & 5 \\
\hline 10 & I learn environmental friendly behavior at work. & 1 & 2 & 3 & 4 & 5 \\
\hline 11 & $\begin{array}{l}\text { There is a supervisory support for the environmental effort } \\
\text { of the employees. }\end{array}$ & 1 & 2 & 3 & 4 & 5 \\
\hline \multicolumn{7}{|c|}{ 2. Internal Factors } \\
\hline \multicolumn{7}{|c|}{ Social Factors } \\
\hline 12 & $\begin{array}{l}\text { My colleagues turn off the switches or machines when not in } \\
\text { use. }\end{array}$ & 1 & 2 & 3 & 4 & 5 \\
\hline 13 & $\begin{array}{l}\text { My colleagues economically use the raw material without } \\
\text { wastage. }\end{array}$ & 1 & 2 & 3 & 4 & 5 \\
\hline 14 & I turn off the switches or machines when not in use. & 1 & 2 & 3 & 4 & 5 \\
\hline 15 & I economically use the raw material without wastage. & 1 & 2 & 3 & 4 & 5 \\
\hline \multicolumn{7}{|c|}{ Attitudes toward Pro-environmental Behavior } \\
\hline 16 & $\begin{array}{l}\text { I'm in favour of behaving pro-environmentally in the } \\
\text { workplace. }\end{array}$ & 1 & 2 & 3 & 4 & 5 \\
\hline
\end{tabular}




\begin{tabular}{|l|l|l|l|l|l|l|}
\hline 17 & $\begin{array}{l}\text { I think it's a good idea for my company as an employer to } \\
\text { support the pro-environmental behaviour in the workplace. }\end{array}$ & 1 & 2 & 3 & 4 & 5 \\
\hline 18 & $\begin{array}{l}\text { The pro-environmental behavior in the workplace is } \\
\text { important to me. }\end{array}$ & 1 & 2 & 3 & 4 & 5 \\
\hline 19 & $\begin{array}{l}\text { I think the pro-environmental behaviour in the workplace } \\
\text { does good. }\end{array}$ & 1 & 2 & 3 & 4 & 5 \\
\hline $\mathbf{3 .}$ Pro - environmental Behaviour & 1 & 2 & 3 & 4 & 5 \\
\hline 20 & At work, I try to learn more about the environment. & 1 & 2 & 3 & 4 & 5 \\
\hline 21 & $\begin{array}{l}\text { At work, I find ways of working that are better for the } \\
\text { environment. }\end{array}$ & 1 & 2 & 3 & 4 & 5 \\
\hline 22 & $\begin{array}{l}\text { At work, I offer ideas for reducing our impact on the } \\
\text { environment. }\end{array}$ & 1 & 2 & 3 & 4 & 5 \\
\hline 23 & $\begin{array}{l}\text { At work, I share my knowledge about the environment with } \\
\text { others. }\end{array}$ & 1 & 2 & 3 & 4 & 5 \\
\hline 24 & $\begin{array}{l}\text { At work, I apply new ideas for reducing our impact on the } \\
\text { environment. }\end{array}$ & 1 & 2 & 3 & 4 & 5 \\
\hline 25 & $\begin{array}{l}\text { At work, I help to create environmental friendly products } \\
\text { and process. }\end{array}$ & 1 & 2 & 3 & 4 & 5 \\
\hline 26 & $\begin{array}{l}\text { At work, I perform environmental tasks that are not required } \\
\text { by my company. }\end{array}$ & 1 & 2 & 3 & 4 & 5 \\
\hline 27 & $\begin{array}{l}\text { At work, I question practices that are likely to hurt the } \\
\text { environment. }\end{array}$ & 1 & 2 & 3 & 4 & 5 \\
\hline 28 & At work, I recycle and reuse materials. & 2 & 3 & 4 & 5 \\
\hline 29 & At work, I try to reduce my energy use. & 3 & 4 & 5 \\
\hline 30 & $\begin{array}{l}\text { At work, I join in environmental activities that are not } \\
\text { required by my job. }\end{array}$ & 1 & 2 & 3 & 4 & 5 \\
\hline 31 & $\begin{array}{l}\text { At work, I encourage others to think about the environmental } \\
\text { protection. }\end{array}$ & 1 & 3 & 4 & 5 \\
\hline 32 & At work, I help others solve environmental problems. \\
\hline
\end{tabular}

